Boom juridisch

Postbus 85576

2508 CG Den Haag

T (070) 3307033

E info@bju.nl

www.boomjuridisch.nl

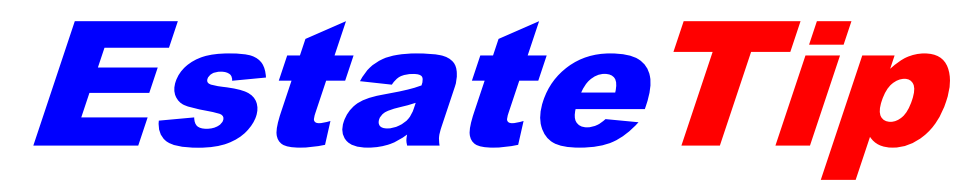

\title{
Kenbaarheid van een verleende handlichting
}

Dankzij een uitspraak van de Rechtbank Oost-Brabant (9 december 2019, ECLI:NL:RBOBR:2019:7024) kunnen we in deze EstateTip Review aandacht besteden aan een minder alledaags 'pfr-fenomeen': handlichting. Daarmee begeven we ons op het gebied van het gezagsrecht en de vertegenwoordigingsbevoegdheid van de wettelijke vertegenwoordiger.

Zoals u weet, zijn zij die de leeftijd van 18 jaren niet hebben bereikt minderjarig. Een uitzondering hierop is de vrouw in de leeftijd tussen de 16 en 18 jaren die meerderjarig is verklaard door de kinderrechter, artikel 1:253ha lid $1 \mathrm{BW}$. Een dergelijk verzoek wordt gedaan door een moeder die ouder is dan 16 jaren en die op grond van haar leeftijd (art. 1:246 BW) onbevoegd is om met het gezag over haar kind te worden belast. De meerderjarigverklaring van artikel 1:253ha heeft als doel dat de vrouw als degene die het gezag heeft, haar kind kan verzorgen en opvoeden.

Maar goed, een minderjarige is, mits handelend met toestemming van diens wettelijke vertegenwoordiger, bekwaam rechtshandelingen te verrichten, voor zover de wet niet anders bepaalt, artikel 1:234 lid $1 \mathrm{BW}$. Toestemming is niet altijd vereist. Denk bijvoorbeeld aan de bevoegdheid van een 16-jarige tot erkenning van een kind (art. 1:204 lid 1 aanhef en onder b BW) of diens testeerbevoegdheid (art. 4:55 lid 1 BW). Los daarvan is een door een onbekwame minderjarige verrichte rechtshandeling nietig, of vernietigbaar, artikel 3:32 lid 2 BW.

In artikel 1:233 leden 2 en $3 \mathrm{BW}$ is vervolgens geregeld dat de toestemmingsverlening door de wettelijke vertegenwoordiger niet algemeen kan zijn, aangezien deze slechts kan worden verleend voor een bepaalde rechtshandeling of een bepaald doel. Dit systeem functioneert in de regel naar tevredenheid omdat niet iedere door een minderjarige verrichte rechtshandeling vatbaar is voor vernietiging. In artikel 1:233 lid $3 \mathrm{BW}$ is immers bepaald dat:

'De toestemming [...] aan de minderjarige [wordt] verondersteld te zijn verleend, indien het een rechtshandeling betreft ten aanzien waarvan in het maatschappelijk verkeer gebruikelijk is dat minderjarigen van zijn leeftijd deze zelfstandig verrichten.'

Het geheel toont z'n zwakke gezicht zodra een minderjarige beroeps- of bedrijfsmatig wil gaan deelnemen aan het rechtsverkeer. Omdat de combinatie van het toestemmingsvereiste an sich enerzijds en het verbod op een 'algemeen werkende toestemming' door de wettelijke vertegenwoordiger anderzijds, dan (nodeloos) beperkend 
zou kunnen werken, is in de tweede afdeling van titel 13 Boek $1 \mathrm{BW}$ de handlichting opgenomen.

$\mathrm{Na}$ een daartoe strekkend verzoek worden bij handlichting door de kantonrechter aan de minderjarige bepaalde bevoegdheden van een meerderjarige toegekend, artikel 1:235 lid $1 \mathrm{BW}$. De kantonrechter geeft uitdrukkelijk aan welke bevoegdheden het betreft. Daarbij is de kantonrechter niet vrij om naar eigen inzicht bevoegdheden toe te kennen. De te verlenen bevoegdheden kunnen slechts betrekking hebben op de ontvangst van inkomsten van de minderjarige zelf en de beschikking daarover, het sluiten van verhuringen en verpachtingen, het in een vennootschap deelnemen en het uitoefenen van een beroep of bedrijf, maar niet op - onder meer - het beschikken over registergoederen of effecten. De ouder(s) zijn onbevoegd voor de bij de handlichting aan de minderjarige verleende bevoegdheden/bekwaamheden.

Het spreekt voor zich dat kenbaarheid van (de omvang van) een verleende handlichting essentieel is. In verband hiermee moet de beschikking waarbij handlichting wordt verleend - alsmede de precieze omvang daarvan - of ingetrokken, worden bekendgemaakt in de Staatscourant en in twee in de beschikking aan te wijzen dagbladen, artikel 1:237 lid 1 BW. Vóór de bekendmaking werkt zomin de handlichting als haar intrekking tegen derden die hiervan onkundig waren, artikel 1:237 lid 2 BW.

Daarmee belanden we bij de uitspraak van de Rechtbank Oost-Brabant. In deze zaak was handlichting verzocht en verleend. Opmerkelijk is hetgeen daarbij werd opgemerkt over de publicatieverplichting:

'2.6. Tot slot wordt het volgende overwogen. De bij deze beschikking verleende handlichting werkt niet reeds vanaf de datum van de beschikking, maar eerst vanaf de datum van publicatie zodat derden daarvan kennis kunnen nemen. Artikel 1:237 lid $1 \mathrm{BW}$ bepaalt dat de beschikking waarbij handlichting is verleend, bekend moet worden gemaakt in de Staatscourant en twee in de beschikking aan te wijzen dagbladen. De bedoeling van de wetgever is daarbij geweest dat op die manier zoveel mogelijk personen kennis kunnen nemen van de handlichting. Tegenwoordig is echter toegang tot internet voor (vrijwel) iedereen beschikbaar en publicatie van de handlichting op internet geeft naar het oordeel van de kantonrechter eenzelfde, of zelfs ruimer, bereik. Nu de Staatscourant op internet beschikbaar is en publicatie daarop bovendien kosteloos is, kan daarmee worden volstaan. Daarnaast zal de beschikking (niet geanonimiseerd) door de griffier worden gepubliceerd op de internetpagina www.rechtspraak.nl, zodat de inhoud daarvan ook via die weg kenbaar is.'

Eigenaardig is de constatering dat de handlichting niet werkt vanaf de datum van de beschikking. Aan te nemen valt dat is bedoeld dat vóór de bekendmaking de handlichting (en intrekking) wel 'intern' werkt, maar niet tegen derden die hiervan 'onkundig waren', in de zin dat zij hiervan niet wisten en niet behoorden te weten. Wat hier ook van zij, dankzij deze praktische rechter wordt het leven voor de derde te goeder trouw er niet makkelijker/overzichtelijker op. Om aanspraak te kunnen maken op bescherming wordt van de onkundige derde immers nog een extra 'zoekslag' gevergd, te weten die op rechtspraak.nl. Zie in dit kader ook Rechtbank Midden-Nederland van 10 april 2015 (ECLI:NL:RBMNE:2015:2402) en Rechtbank Noord-Holland-Noord van 20 november 2019, (ECLI:NL:RBNHO:2019:10285) waar publicatie op rechtspraak.nl in de plaats kwam van die in de Staatscourant en verder kon worden volstaan met slechts één dagblad. 
In geval van de 'exoot' handlichting is dit wellicht nog wel verdedigbaar, maar te hopen is dat een dergelijke 'praktische' interpretatie van de wet achterwege blijft bij andere in Boek 1 BW te beschermen derden...

Hoe dan ook,

Tot volgende week!

Mr. F.M.H. Hoens

Radboud Universiteit Nijmegen

cholsBurgerhartSchols

\section{Boomjuridisch}

www.scholsburgerhartschols.nl www.boomjuridisch.nl

(C) 2020 Boom juridisch | ScholsBurgerhartSchols

Hoewel de uiterste zorg is besteed aan de inhoud van EstateTip Review aanvaarden de uitgever en de redactie geen aansprakelijkheid voor onvolledigheid of onjuistheid. 